\title{
REDUCTION IN KNEE PAIN SYMPTOMS IN ATHLETES USING AN ACUPUNCTURE PROTOCOL
}

\section{REDUÇÃO DA SINTOMATOLOGIA DOLOROSA DE JOELHO EM ATLETAS UTILIZANDO PROTOCOLO DE ACUPUNTURA}

\author{
ana Paula Rehme Siqueira ${ }^{1}$, Lucas Menghin Beraldo ${ }^{1}$, Eddy Krueger ${ }^{2}$, Leandra Ulbricht ${ }^{1}$ \\ 1. Universidade Tecnológica Federal do Paraná, Curitiba, PR, Brazil. \\ 2. Neural Engineering and Rehabilitation Laboratory. Graduate program in Rehabilitation UEL-UNOPAR. Universidade Estadual de Londrina - UEL, Londrina, PR, Brazil.
}

\section{ABSTRACT}

Pain in the lower limbs is common in athletes and a limiting factor in performance. Acupuncture has shown positive effects as an analgesic treatment and may potentially be used for pain reduction in runners. This study aimed to analyze the parameters associated with knee pain by correlating strength parameters of the musculature assessed in runners treated with acupuncture. A descriptive longitudinal study was conducted on 34 runners of both sexes aged 20 to 52 years, who presented with knee-related pain from January to June, 2015. Two pain questionnaires and a maximal strength test with electromyographic evaluation of the rectus femoris, vastus lateralis, and medialis muscles were used, and patients were monitored during five follow-up visits after an acupuncture protocol. All participants reported experiencing a decrease in knee pain after treatment. The affected limbs showed an increase in average strength by $34 \%$ and $25 \%$ compared to the contralateral limb. An increase in the number of motor units recruited for the three muscles was observed in both limbs. In conclusion, the proposed acupuncture protocol was effective in reducing pain symptoms in the knee region of athletes, thus influencing their gain in strength and muscle balance. Level of Evidence IV, Case series.

Keywords: Acupuncture. Analgesia. EMG. Knee joint. Athletes.

\section{RESUMO}

A dor em membros inferiores é comum em atletas e representa um aspecto limitante ao rendimento. Buscando atenuação para a dor desta população, utiliza-se a acupuntura por apresentar bons efeitos na analgesia. Objetivo: analisar os parâmetros relacionados à dor de joelho correlacionando os parâmetros de força das musculaturas avaliadas em corredores submetidos a tratamento de acupuntura. Métodos: Foi realizado um estudo longitudinal, de janeiro a junho de 2015, com 34 corredores de 20 a 52 anos de ambos os sexos, que apresentassem dor de joelho. Foram aplicados dois questionários de dor e um teste de força máxima com avaliação eletromiográfica dos músculos reto femoral, vasto lateral e medial, com cinco atendimentos seguindo um protocolo de acupuntura. Resultados: Todos os voluntários relataram diminuição da dor de joelho após o tratamento. A média de força do membro afetado teve incremento de $34 \%$ e do membro contralateral de $25 \%$. Verificou-se aumento no número de recrutamento de unidades motoras para os três músculos avaliados em ambos os membros. Conclusão: O protocolo proposto se mostrou eficaz na diminuição da sintomatologia dolorosa na região de joelhos de atletas corredores, interferindo no ganho de força e no equilíbrio muscular. Nível de Evidência IV, Série de casos.

Descritores: Analgesia por Acupuntura. Eletromiografia. Articulação do joelho. Atletas.

Citation: Siqueira APR, Ulbricht L, Krueger E, Beraldo LM. Reduction in knee pain symptoms in athletes using an acupuncture protocol. Acta Ortop Bras. [online]. 2018;26(6):418-22. Available from URL: http://www.scielo.br/aob.

\section{INTRODUCTION}

According to epidemiological studies, $27 \%$ to $70 \%$ of runners incur some form of injury over a 1-year period, which can cause discomfort during training and lead to performance below expected levels in competitions. ${ }^{1}$

Acupuncture therapy may be beneficial for attenuating and/or resolving pain in runners, as this technique is known for its analgesic effects when applied in patients with chronic knee pain. ${ }^{2}$ This approach is widely used in Brazil and consists of the insertion of stainless steel needles at specific points in several areas of the body. ${ }^{3}$ Needles can be inserted either at or near the pain site and may also be inserted at points associated with the underlying symptoms. ${ }^{4}$

In order to provide a reliable level of scientific evidence for acupuncture techniques to guide clinical practice, this study sought to analyze the effects of a treatment protocol using acupuncture and to report the effects on pain parameters in the knee region of runners; the results presented here provide a clear methodological description favoring the application and reproducibility of this technique in clinical practice.

All authors declare no potential conflict of interest related to this article. 


\section{MATERIALS AND METHODS}

The study sample consisted of 34 street runners from the city of Curitiba, of both sexes, aged between 20 and 52 years, who presented pain in the knee region.

Runners with compromising lesions in the lower limbs that could prevent a proper evaluation, pregnant runners, and runners with cognitive impairments that could interfere with the understanding of any part of the study were excluded. The survey was conducted after participants signed an informed consent form. This research protocol was approved by the Committee on Ethics in Human Research at the Universidade Tecnológica do Paraná (under the number CAEE: 30166314.2.0000.5547).

The McGill Pain Questionnaire was used together with the visual analog scale (VAS) and the Faces Pain Scale to assess pain intensity; the assessments were conducted before and after treatment. In order to ensure the reliability of the protocols, the participants were not provided access to their answers before treatment.

Each individual's skin was prepared by trichotomy and cleansing with a $70 \%$ alcohol solution in the areas specified for the placement of the surface electrodes (10-mm diameter $\mathrm{Ag} / \mathrm{AgCl}$ electrodes, Meditrace $\AA$ ), which were positioned in a bipolar configuration. The reference electrode was positioned on the left side of the acromion process.

The quadriceps muscles were assessed during knee extension movements with maximal isometric contraction, performed using a leg-extension chair device (Figure 1) with the participant sitting, the trunk sustained by the dorsal support of the chair, and the upper limbs crossed over the chest. The contraction was performed with the lower limb flexed at $60^{\circ}$. A maximum contraction of 3 seconds was requested and was repeated three times, with a rest interval of 2 minutes between contractions. The electromyographic data of the rectus femoris, vastus lateralis, and vastus medialis muscles were analyzed. Both the affected limb and the contralateral limb of the participants were assessed; the latter was used as a control in the data analysis.

The extensor chair was fitted with a load cell that registered the signal strength of the knee extension movement (Figure 1). An electromyography (EMG) device (EMG Systems ${ }^{\circledR}$ Brazil) was used

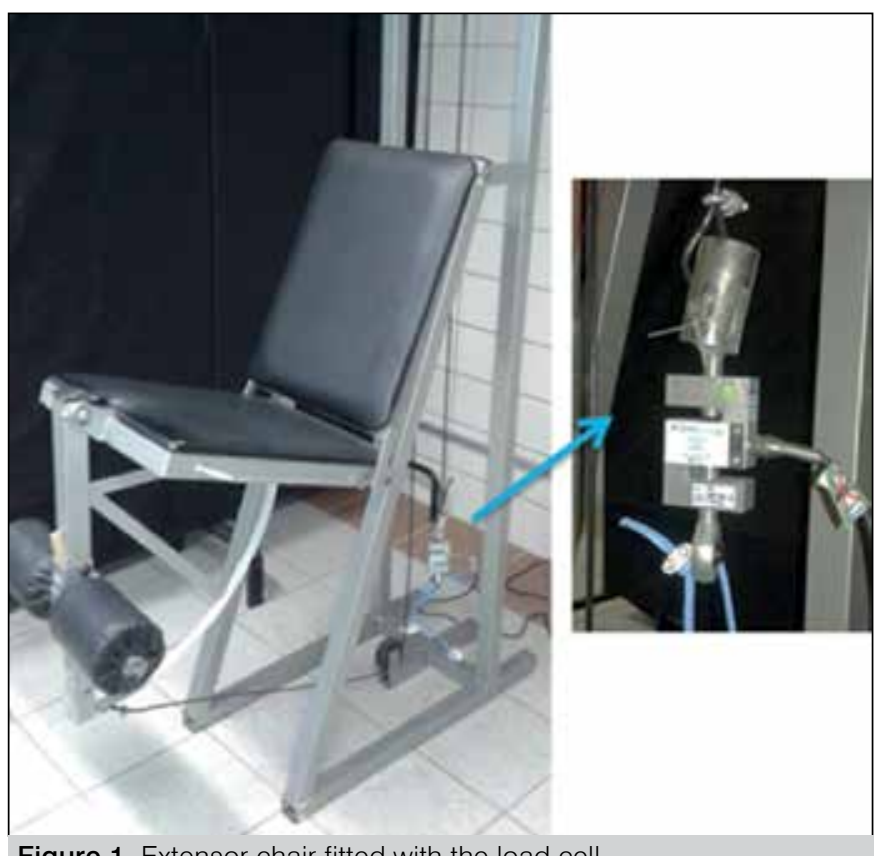

Figure 1. Extensor chair fitted with the load cell and set with an acquisition frequency of $1-\mathrm{kHz}$ signals. The $\mathrm{Ag} /$ $\mathrm{AgCl}$ electrodes were positioned on the distal third of the rectus femoris, vastus medialis, and vastus lateralis muscles.

The electromyograph was previously calibrated by the support staff of EMG Systems $₫$, Brazil. The load cell was calibrated with a manual Crown $₫$ dynamometer with a capacity of 50-kilogram force (kgf) with 5-kgf divisions and a precision equal to $1 \%$ of the total capacity. The calibration was performed considering variations of $5 \mathrm{kgf}$ (5 kgf, $10 \mathrm{kgf}, 15 \mathrm{kgf}$, and so forth). Force correction was performed individually by

$$
C C \text { calb }=\left(C C n-C C_{\text {baseline }}\right) .65=(\mathrm{kg} f)
$$

where $C C$ call is the corrected value, $C C n$ the crude value, $C C_{\text {baseline }}$ the residual value of the load cell, and 65 the conversion factor of volts $(\mathrm{V})$ to $\mathrm{kgf}$.

The signals were processed using MATLAB® R2008a (MathWorks, Inc) with third-order Butterworth type pass-through $30-450 \mathrm{~Hz}$ filtering, as well as band-reject type filters on the harmonics of the electric grid $(60,120,180,240,300,360$, and $420 \mathrm{~Hz})$. For the spectral domain, the median frequency descriptor (MDF) was extracted using the fast Fourier transform, algorithm, according to the following equation:

$$
M F=\int_{0}^{M F} P(f) d f=\frac{1}{2} \int_{0}^{f s / 2} P(f) d f
$$

where $M F$ is the median frequency and the power spectrum.

Time-domain EMG signal processing was performed using the median absolute amplitude equation, shown as the energy median (ME), as defined in the equation

$$
M E_{\text {axis }}=\frac{1}{2}\left(\left|E M G_{\text {axis } \mid \frac{n}{2}}+\right| E M G_{\text {axis } \mid \frac{n}{2}+1}\right)
$$

where $M E$ is the median energy (median absolute amplitude) and is the EMG signal.

The acupuncture protocol used was developed for this study, based on pressure points of systemic acupuncture with evidence supporting a decrease in pain symptomatology in the knee region. DongBang ${ }^{\circledR}$ needles (DongBang Acupuncture Inc., Seoul, South Korea) of $0.25 \times 30 \mathrm{~mm}$ were used. The first acupuncture application was performed immediately after EMG data were collected. The volunteer was placed in a supine position on a stretcher for all applications of this protocol.

After the first application, four additional weekly acupuncture sessions were performed, each with a duration of 60 minutes. The time of needle permanence at each point was 40 minutes. Needle insertion was performed in the following order: E35 (Dubi), EX-LE-4 (Neixiyan), and the cranial point (sensory and motor areas in the cranial region contralateral to the affected limb). The needles were withdrawn in the same sequence.

\section{Statistical analysis}

Statistical procedures were performed using the Statistical Package for Social Sciences (SPSS) version 21.0 and Microsoft Office Excel 2010. The Shapiro-Wilk test was used to verify the normality of distributions. Normally distributed variables were described by means and standard deviations (SD), and the values before and after acupuncture application were compared using dependent t-tests.

Variables with non-normal distributions were assessed with nonparametric procedures; descriptive data were presented 
as the median and interquartile range, and comparisons were performed using the Wilcoxon test. Pain scores were assessed with the same nonparametric procedures, due to the subjective nature of the evaluation and the ordinal characteristics of the variables. Maximum and minimum values were used for the description of these scores.

Comparisons between variables before and after the acupuncture sessions were reported as absolute differences (delta, $\Delta$ ) and relative (\%) changes with respect to the respective central tendency measure. The significance level was set at $p<0.05$ for all analyses.

\section{RESULTS}

The sample comprised 34 volunteers of both sexes (25 males [73.53\%] and nine females) with a mean age of 34 years, a mean weight of $75 \mathrm{~kg}$, a mean height of $1.71 \mathrm{~m}$, and a mean body mass index (BMI) of $25 \mathrm{~kg} / \mathrm{m}^{2}$.

Athletes reported, on average, a history of 7 years of practice and generally trained 7 hours per week. In addition, they reported 2 years and 9 months of injury on average, with 18 athletes reporting pain in the right knee and 16 reporting pain in the left knee.

Table 1 shows the values of force applied by the quadriceps muscles. Table 2 presents the amplitudes of the contraction signal of the affected and of the contralateral limb. Table 3 presents the median frequency (Fmed) of the affected and contralateral limbs. All tables show the values obtained before and after treatment, as well as the improvement achieved in each limb as a percentage, the delta value (difference between the first and second evaluation), and the $p$-value obtained from the statistical analyses.

Table 4 shows the data related to pain in the knee region before and after the implementation of the protocol, evaluated using the McGill Pain Questionnaire and VAS assessments.

Table 1. Analysis of the strength of the quadriceps muscles.

\begin{tabular}{c|c|c|c|c|c}
\hline \multicolumn{7}{c}{ Force (kgf) } \\
\hline & Before & After & $\%$ & $\Delta$ & P-value \\
\hline Affected limb $^{\mathrm{a}}$ & $17.14 \pm 17.14$ & $25.12 \pm 18.65$ & 47 & 7.98 & 0.001 \\
\hline Contralateral limb $^{\mathrm{a}}$ & $25.12 \pm 15.71$ & $26.66 \pm 17.30$ & 6 & 1.54 & 0.001 \\
\hline amean+standard deviation
\end{tabular}

Table 2. Signal amplitude of contraction.

Signal amplitude (uV)

\begin{tabular}{|c|c|c|c|c|c|}
\hline \multirow[b]{2}{*}{ Muscle } & \multicolumn{5}{|c|}{ Affected Limb } \\
\hline & $\begin{array}{c}\text { Before } \\
\text { (median/Amplnt) }\end{array}$ & $\begin{array}{c}\text { After } \\
\text { (median/Amplnt) }\end{array}$ & $\%$ & $\Delta$ & P-value \\
\hline Rectus femoris ${ }^{\mathrm{a}}$ & $233.81 \pm 241.41$ & $333.47 \pm 263.70$ & 43 & 99.66 & 0.001 \\
\hline Vastus lateralis ${ }^{\mathrm{a}}$ & $263.96 \pm 127.19$ & $307.37 \pm 303.48$ & 16 & 43.41 & 0.025 \\
\hline \multirow[t]{2}{*}{ Vastus medialis ${ }^{a}$} & $206.02 \pm 226.27$ & $256.59 \pm 310.49$ & 25 & 50.57 & 0.001 \\
\hline & \multicolumn{5}{|c|}{ Contralateral Limb } \\
\hline Rectus femoris ${ }^{a}$ & $300.29 \pm 247.57$ & $352.70 \pm 268.51$ & 17 & 52.41 & 0.023 \\
\hline Vastus lateralis $^{\mathrm{a}}$ & $267.64 \pm 175.42$ & $339.44 \pm 254.88$ & 27 & 71.80 & 0.002 \\
\hline Vastus medialis $^{a}$ & $205.63 \pm 146.23$ & $271.05 \pm 261.56$ & 32 & 65.42 & 0.029 \\
\hline
\end{tabular}

Table 3. Median frequency.

\begin{tabular}{c|c|c|c|c|c}
\hline \multicolumn{5}{c}{ Median frequency } \\
\hline Muscle & Affected Limb \\
\hline Mean & Before & After & $\%$ & $\Delta$ & P-value \\
\hline Rectus femoris $^{\mathrm{a}}$ & $104.70 \pm 11.02$ & $105.61 \pm 11.35$ & $1 \%$ & 0.91 & 0.476 \\
\hline Vastus lateralis $^{\mathrm{b}}$ & $122.00 \pm 31.50$ & $111.50 \pm 32.50$ & $-9 \%$ & -10.5 & 0.019 \\
\hline Vastus medialis $^{\mathrm{a}}$ & $102.67 \pm 11.12$ & $106.64 \pm 12.97$ & $4 \%$ & 3.97 & 0.036 \\
\hline & \multicolumn{5}{c}{ Contralateral Limb } \\
\hline Rectus femoris $^{\mathrm{a}}$ & $105.73 \pm 12.00$ & $104.73 \pm 13.03$ & $-1 \%$ & -1.00 & 0.507 \\
\hline Vastus lateralis $^{\mathrm{b}}$ & $128.00 \pm 33.75$ & $113.00 \pm 36.25$ & $-12 \%$ & -15.00 & 0.002 \\
\hline Vastus medialis $^{\mathrm{a}}$ & $105.02 \pm 11.57$ & $106.94 \pm 11.91$ & $2 \%$ & 1.92 & 0.294 \\
\hline
\end{tabular}

amean \pm standard deviation, dependent t-test; ${ }^{\mathrm{b}}$ median \pm interquartile range, Wilcoxon test.

\begin{tabular}{|c|c|c|c|c|c|c|c|}
\hline & Pain & Min & Max & $\begin{array}{c}\text { Median } \\
\text { Interquartile range }\end{array}$ & Improvement & $\Delta$ & P-value* \\
\hline \multirow{2}{*}{ VAS } & Before & 04 & 10 & $6.35 \pm 1.66$ & \multirow{2}{*}{$48.03 \%$} & \multirow{2}{*}{$\mid-3.30$} & \multirow{2}{*}{0.001} \\
\hline & After & 00 & 06 & $3.05 \pm 1.66$ & & & \\
\hline \multirow{2}{*}{ McGill } & Before & 07 & 56 & $19.17 \pm 10.05$ & \multirow{2}{*}{$58.89 \%$} & \multirow{2}{*}{-11.29} & \multirow{2}{*}{0.001} \\
\hline & After & 01 & 20 & $7.88 \pm 5.17$ & & & \\
\hline
\end{tabular}

*Wilcoxon test.

\section{DISCUSSION}

The mean strength of the quadriceps muscle group of the affected limb was $17 \mathrm{kgf}$ before treatment and increased to $25 \mathrm{kgf}$ after acupuncture treatment. For the contralateral limb, the mean strength was $25 \mathrm{kgf}$ at the first and $26 \mathrm{kgf}$ at the second assessment.

The mean force of the quadriceps both in the affected limb and in the contralateral limb showed a significant gain $(p<0.001$ for both). These results are supported by previously published data $^{5,6}$ claiming that when a decrease in symptoms of pain in the treated region occurs, a gain in strength can be achieved. Since the volunteers perceived a reduction in previously experienced pain, they were able to train properly again, as pain is a limiting factor for muscle function. ${ }^{7}$

The affected limb showed a $47 \%$ gain in mean strength while in the contralateral limb, the mean strength increased by $6 \%$; this was sufficient to produce a similar final mean strength in both limbs, indicating a balance of muscle strength between the limbs (25.12 kgf and $26.66 \mathrm{kgf})$. Muscle imbalance is one of the most common factors reported as a likely cause of sports injuries. ${ }^{8,9}$ Bilateral deficits greater than $10-15 \%$ are indicators of muscular imbalances and may also be associated with a high risk of injury (joint, muscular, and tendinous) and a reduction in sports performance. ${ }^{10,11}$ When subjected to the acupuncture protocol, the volunteers not only experienced a reduction in pain in the knee region, but also gained strength in the affected limb; they could thus balance muscle strength between the affected and the contralateral limb, which consequently promotes the prevention of future injuries.

Regarding the amplitude of the electromyographic signal, there was an increase in the recruitment number of motor units after 
treatment for the three muscles evaluated, for both the affected and the contralateral limb.

The rectus femoris muscle of the affected limb showed a significant improvement, with a gain of $43 \%(p<0.001)$. The vastus medialis muscle showed a gain of $25 \%(p<0.001)$ and the vastus lateralis muscle a gain of $16 \%(p=0.025)$. A different pattern was observed in the contralateral limb, where the biggest improvement occurred in the vastus medialis muscle, with a gain of $32 \%$ ( $p$ $=0.023$ ), followed by the vastus lateralis muscle with a gain of $27 \%(p=0.029)$, and the femoral rectus muscle with a gain of $17 \%(p=0.002)$.

With regard to the amplitude of the electromyographic signal, there was a significant difference in the number of recruited motor units after treatment in both limbs in the three muscles evaluated. Muscular hypertrophy and changes in motor unit recruitment are important factors associated with strength development. An increase in signal amplitude has been reported to represent an increase in the recruitment capacity of motor units upon the application of various strength training schemes. ${ }^{12}$

Another phenomenon that generates an increase in the amplitude of the electromyographic signal is the increased synchronization of motor units, due to an increase in the number of action potentials firing from motor units of multiple synergistic muscle groups over the same unit of time. ${ }^{12,13}$ The function of synchronization is to increase the rate of force development during rapid contractions, as was observed in this study. Synchronization of motor units improves intra- and intermuscular coordination, thereby increasing the muscle's capacity to generate the greatest force..$^{2}$

With regard to the Fmed, there was no difference in action potential speed in the muscles before and after treatment in both the affected and the contralateral limb. This similarity between the values obtained before and after acupuncture treatment was somewhat expected, as different authors have observed a reduction in Fmed in the muscles of the thigh with or without using fatigue protocols. ${ }^{14}$

When an increase in the firing frequency occurs, this represents an increase in the conduction velocity of the action potentials of the larger-diameter motor units. ${ }^{12}$ The results of this study indicate that there was an increase in the temporal domain but not in frequency, since no specific muscular training was performed. There was no general modification in neural activation in this population of athletes, but with a reduction in pain and thus in physical limitations, more motor units could be activated for the exercises already performed by the athletes. A variety of adaptations is responsible for increasing strength, power, and rate of strength development. In sedentary individuals, neural adaptations predominately occur at the beginning of a training program; it is thus plausible that certain training methods and strategies effective for such a population do not induce the same magnitude of adaptations in trained individuals. ${ }^{12}$

All volunteers reported feeling an improvement of pain symptoms in the knee region at the end of the 5-week treatment period. Regarding the assessment of pain, classified by the VAS, the mean for the affected limb was 6.35. After implementation of the protocol, the mean VAS score decreased to 3.05, which represents a reduction of $48.03 \%(p=0.001)$. Taking into account the values obtained with this scale, 28 volunteers showed a decrease in pain of at least 50\%, five volunteers reported decreased pain but with the reduction not exceeding $50 \%$, and only one volunteer reported feeling, numerically, the same initial and final degree of pain.

The initial value of the sum of the responses in the McGill Pain Questionnaire was 19.17, which subsequently decreased to 7.88, with an average pain reduction of $58.89 \%$. The total number of descriptors chosen before the implementation of the acupuncture protocol was 255 , and the mean was 7.50 . In the assessment following the implementation of the acupuncture protocol, the number of descriptors fell to 153, with a mean of 4.50 (improvement of $40 \%, p=0.001$ ).

Both methods used to evaluate pain showed a statistically significant reduction in pain, corroborating the results of other studies regarding the effects of acupuncture. ${ }^{2,15-20}$ For this reason, acupuncture has been proposed for the treatment of several painful conditions.

Reis et al. ${ }^{18}$ evaluated the effects of traditional acupuncture on pain levels and on the performance of the autonomic nervous system through the variability of the heart rate $(\mathrm{HR})$ of individuals with hypersensitive myofascial trigger points located in the trapezius and/or rhomboid muscles. A clinical study was carried out with 11 participants of both sexes, with ages ranging from 18 to 50 years. Treatment with acupuncture reduced pain and significantly reduced the HR. The study also showed that all participants displayed a decrease in symptomatology compared to the initial condition after acupuncture, presenting an initial mean score of 7.6 on the VAS and a final mean score of 3.6, a $47.36 \%$ improvement. The present study revealed a similar mean improvement (48.03\%), with an initial mean of 6.35 and a final mean score of 3.05 on the VAS.

A reduction in pain symptoms as the one reported by the volunteers in the current study enables runners to perform running movements in a proper manner, because it eliminates the compensation behavior that commonly occurs when pain is present. Al Snih et al., ${ }^{19}$ who conducted a study with 544 participants, and Neogi et al., ${ }^{20}$ who conducted another study with 2940 participants, both reported that the presence of pain was associated with a reduction in motor function in both men and women. Clinical experience shows that when a particular sport is poorly executed, it generates intense overload. Furthermore, asymmetry can lead to complications and some undesirable postural alterations, as the random repetition of specific movements in practice may lead to the accumulation of unilateral load. ${ }^{21}$

\section{CONCLUSIONS}

The acupuncture protocol proposed in this study led to a significant improvement in the treatment of knee pain symptoms of runners. It enabled participating athletes to execute movements characteristic of running in a more appropriate way, by promoting the balance in muscle strength between the limbs and thus preventing sports injuries and changes in sport performance.

The analysis of electromyographic signals is an appropriate methodology for monitoring alterations related to changes in the pre- and post-treatment recruitment of motor units and in the development of muscular strength.

AUTHORS' CONTRIBUTIONS: Each author contributed individually and significantly to the preparation of the manuscript. APRS (0000-0002-7306-326X) and LU (0000-0002-9514-2938) were the main contributors in drafting the manuscript, and LU was responsible for data tabulation and statistical analysis. APRS performed the data collection with the participants. APRS and EK (0000-0003-3890-1595) carried out the study procedures to obtain variables and tabulate the data. LMB (0000-0001-7812-1011) performed the statistical analyses and APRS and LMB analyzed the statistical data. APRS carried out the bibliographic research. LU and EK reviewed the manuscript. *ORCID (Open Researcher and Contributor ID). 


\section{REFERENCES}

1. Pereira JLR. Lesão em corredores: aspectos preventivos através de uma abordagem epidemiológica [monografia de conclusão de curso]. Porto Alegre: Universidade Federal do Rio Grande do Sul; 2010.

2. Hinman RS, McCrory P, Pirotta M, Relf I, Crossley KM, Reddy P, et al. Efficacy of acupuncture for chronic knee pain: protocol for a randomized controlled trial using a Zelen design. BMC Complementary and Alternative Medicine. 2012;12(1):1.

3. Rocha SP, Fernandez FHB, Gallian DMC. A acupuntura no Sistema Único de Saúde no município de São Paulo: história e memória. Rev Bras Med Fam Comunidade. 2012;7(Supl 1):21.

4. Kieling, G. Risco na prática da acupuntura e sua prevenção: Uma revisão da literatura. Jornal de Práticas Integrativas Complementares. 2013;1(1):49-82.

5. Santos RL, Souza MLSP, Santos FA. Estimulação elétrica neuromuscular na disfunção patelofemoral. Revisão de literatura. Acta Ortop Bras. 2013;21(1):52-8.

6. Medeiros JF. Efeitos do programa de exercícios sobre a cervicalgia e as aptidões físicas relacionadas à saúde: estudo de caso. Revista Brasileira de Prescrição e Fisiologia do Exercício. 2013;7(42):508-16.

7. Wibelinger LM, Batista JS, Vidmar MF, Kayser B, Pasqualotti A, Schneider RH Effects of conventional physiotherapy and wii therapy on pain and functional capacity of elderly women with knee osteoarthritis. Rev Dor. 2013;14(3):196-9.

8. Carvalho P, Cabri J. Avaliação isocinética da força dos músculos da coxa em futebolistas. Revista Portuguesa de Fisioterapia no Desporto. 2007;1(21):4-13.

9. Schwartzmann NS, Dos Santos FC, Bernardinelli E. Dor no ombro em nadadores de alto rendimento: possíveis intervenções fisioterapêuticas preventivas. Rev Ciênc Méd. 2012;14(2):199-212.

10. Croiser, J. L. Factors associated with recurrent hamstring injuries. Sports Med. 2004;34(10):681-95.

11. Vidmar MF, Dellagerisi M, Kappel MD, Pasqualotti A, Silva MF, Pimentel GL, et al. Avaliação da performance muscular em atletas profissionais de futebol de campo. Rev Bras Ciênc Mov. 2013;21(2):82-8.

12. Ide BN, Muramatsu LV, Ramari C, Macedo DV, Palomari ET. Adaptações Neurais ao Treinamento de Força. Acta Brasileira do Movimento Humano. 2014;4(5):1-16.

13. Folland JP, Williams AG. The adaptations to strength training: morphological and neurological contributions to increased strength. Sports Med. 2007;37(2):145-68.

14. Masuda T, Kizuka T, Zhe JY, Yamada H, Saitou K, Sadoyama T, Okada M. Influence of contraction force and speed on muscle fiber conduction velocity during dynamic voluntary exercise. J Electromyogr Kinesiol. 2001;11(2):85-94.

15. Oliveira CC, Maugin C, Oliveira ECF, Melo FDP, Silva FCA, Dias FEJ, et al. A dor e o controle do sofrimento. Lab. de Psicofisiologia do Departamento de Fisiologia e Biofísica do Instituto de Ciências Biológicas da UFMG. Revista de Psicofisiologia. 1997;1(1):1-26.

16. Irnich D, Behrens N, Molzen H, Konig A, Gleditsch J, Krauss M, et al. Randomised trial of acupuncture compared with conventional massage and "sham" laser acupuncture for treatment of chronic neck pain. BMJ. 2001;322(7302):1574-8.

17. Menezes CNB, Silva EF, Passareli-Carrazzoni P, Silva JA. A percepção de dor a partir da visão de médicos e estudantes universitários. Rev Dor. 2006;7(3):809-18.

18. Reis MCR, Salles M, Licurci MGB, Fagundes AA. Efeito da acupuntura no alívio da dor de pontos gatilhos miofasciais hipersensíveis dos músculos trapézio e romboide e sua ação sobre a variabilidade da frequência cardíaca. XV Encontro Latino Americano de Iniciação Científica, Universidade do Vale do Paraíba, 2011.

19. Al Snih S, Raju MA, Peek MK, Ottenbacher KJ. Pain, lower-extremity muscle strength, and physical function among older Mexican Americans. Arch Phys Med Rehabil. 2005;86(7):1394-400.

20. Neogi T, Nevitt M, Yang M, Curtis J, Torner J, Felson DT. Consistency of knee pain: correlates and association with function. Osteoarthritis Cartilage. 2010;18(10):1250-5. 